DOI: 10.4274/tod.galenos.2019.16023

Turk J Osteoporos 2019;25:49-52

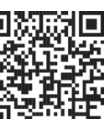

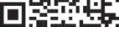

\title{
Is There Any Relationship Between Serum Endocan Levels and Carotid Intima-media Thickness in Patients with Fibromyalgia?
}

\author{
Fibromiyaljili Hastalarda Serum Endokan Düzeyleri ile Karotis Intima-medya Kalınlığı \\ Arasında Ilişki Var mı?
}

\author{
(D) Fatih Bağcıer, (D) Fatih Hakan Tufanoğlu*, (D) Özgür Kadıçeşme** \\ Kars Harakani State Hospital, Clinic of Physical Theraphy and Rehabilitation, Kars, Turkey \\ *Kars Harakani State Hospital, Clinic of Radiology, Kars, Turkey \\ **Kars Harakani State Hospital, Clinic of Biochemistry, Kars, Turkey
}

\section{Abstract}

Objective: Although the pathophysiology of Fibromyalgia syndrome (FMS) has not yet been completely elucidated, it has been suggested that inflammation and endothelial dysfunction occur in patients with FMS. In recent years, endocan has been reported as an important biomarker for inflammation and endothelial dysfunction. It is important to assess carotid intima-media thickness (CIMT) in the evaluation of early atherosclerotic vascular diseases. In this study, we investigated this mechanism by measuring serum endocan levels and CIMT in patients with FMS and evaluated whether there is a correlation between them.

Materials and Methods: Serum samples collected from 40 female patients diagnosed with FMS (the patient group) for the first time and 40 healthy female participants' (the control group) endocan levels and CIMT ultrasonography were investigated, and the values of the two groups were compared.

Results: Serum endocan levels and CIMT results were significantly higher in the patient group than in the control group ( $<<0.001$ ). In addition, a very weak correlation was found between CIMT and endocan levels in patients with FMS.

Conclusion: Increased subclinical inflammation, endothelial dysfunction, and early atherosclerosis play an important role in the pathophysiology of FMS. Increased endocan levels, CIMT, and the correlation between them will contribute to elucidating this mechanism. Keywords: Carotid intima-media thickness, fibromyalgia, endocan, correlation

\section{Öz}

Amaç: Fibromiyaljinin patofizyolojisi henüz tam olarak aydınlatılmamış olmakla birlikte, fibromiyaljili hastalarda enflamasyon ve endotel disfonksiyonunun ortaya çıktığı ileri sürülmüştür. Son yıllarda, endokan enflamasyon ve endotel disfonksiyonu için önemli bir biyobelirteç olarak bildirilmiştir. Erken aterosklerotik vasküler hastalıkları değerlendirmede karotis intima media-kalınlığının (KiMK) değerlendirilmesi önemlidir. Bu çalışmada, fibromiyalji hastalarında serum endokan düzeylerini ve KiMK'yi ölçerek bu mekanizmayı araştırdık, aralarında bir korelasyon olup olmadığını değerlendirdik.

Gereç ve Yöntem: İlk kez fibromiyalji tanısı alan 40 kadın hastadan toplanan serum örnekleri ve 40 sağlıkı kadın endokan düzeyleri ve KiMK ultrasonografi ile incelendi ve iki grubun değerleri karşllaştııılı.

Bulgular: Hasta grubunda serum endokan seviyeleri ve KiMK sonuçları kontrol grubuna göre anlamlı olarak yüksek olarak bulunmuştur $(p<0,001)$. Ayrıca FMS'li hastalarda KiMK ile endokan seviyesi arasında çok zayıf bir korelasyon görüldü.

Sonuç: Fibromiyaljinin patofizyolojisinde artmış subklinik enflamasyon, endotelyal disfonksiyon ve erken ateroskleroz önemlidir. Artan endokan düzeyi, KiMK ve aralarında korelasyon görülmesi bu mekanizmayı aydınlatmaya katkı sağlar. Anahtar kelimeler: Karotis intima-media kalınlığı, fibromiyalji, endokan, korelasyon

Address for Correspondence/Yazışma Adresi: Fatih Bağcıer MD, Kars Harakani State Hospital, Clinic of Physical Theraphy and Rehabilitation, Kars, Turkey Phone.: +90 5442429042 E-mail: bagcier_42@hotmail.com ORCID ID: orcid.org/0000-0002-6103-7873 Received/Geliş Tarihi: 27.10.2018 Accepted/Kabul Tarihi: 30.03.2019 


\section{Introduction}

Fibromyalgia syndrome (FMS) is a chronic Pain syndrome characterized by widespread pain, sensitivity, sleep disturbance, fatigue, cognitive dysfunction, and emotional stress (1). Although the pathophysiology of FMS has not yet been completely elucidated, it has been suggested that inflammation and endothelial dysfunction occur in patients with FMS $(2,3)$. Studies have shown that serum levels of proinflammatory cytokines (TNF-a, IL-6) and chemokines (Tarc, MIG) are higher in patients with FMS than in the healthy population (4-6). Furthermore, carotid intima-media thickness (CIMT) used to evaluate early atherosclerotic vascular diseases has been shown to be increased in FMS patients (2). Some studies have also shown that the level of endocan, which is a novel marker of inflammation and endothelial dysfunction, correlates with CIMT in various inflammatory diseases $(7,8)$. The aim of this study was to evaluate serum endocan levels, which are important in the etiopathogenesis of FMS, and to evaluate the correlation between endocan levels and CIMT.

\section{Materials and Methods}

The study included patients admitted to the Physical Medicine and Rehabilitation Polyclinic of Kars Harakani State Hospital, who were diagnosed with FMS based on the 2016 ACR criteria. Exclusion criteria included patients aged $<18$ years or $>70$ years, the presence of any acute or chronic inflammatory disease, history of anti-inflammatory drug use, history of chronic illness (such as heart failure, coronary artery disease, liver failure, renal failure, chronic obstructive pulmonary disease, and diabetes mellitus), pregnancy or suspicion of pregnancy, and history of malignancy. The control group was formed of patients with Myofascial Pain syndrome with a trigger point in the upper trapezius muscle and pain durations were recorded.

Written informed consent was obtained from all the study participants. The study were approved by the Kafkas University Faculty of Medicine of Local Ethics Committee (protokol no: 80576354-050-99/131).

The demographic characteristics of patients, including age, weight, height, and body mass index, were recorded. Bilateral CIMT measurements of CIMT were taken using ultrasonography by an experienced radiologist using a linear probe (Figure 1) (7-12 MHz, B-mode, Toshiba Aplio 500, Japan). Serum endocan levels were measured using the commercial Human endothelial cell specific molecule 1 (ESM1) ELISA Kit (catalog no: E-EL-H1557).

\section{Statistical Analysis}

Conformity of the data to normal distribution was assessed using the Kolmogorov-Smirnov test. To determine any difference in CIMT and endocan values between the patient and control groups, the Student's t-test or the Mann Whitney U-test was applied. Correlations between endocan levels and CIMT values were assessed using the pearson or spearman correlation test. Power Analysis: When data were evaluated by assuming that type I error was 0.05 and the power of the study was $80 \%$ **, the sample size was calculated as at least 28 patients necessary in each group.

\section{Results}

The demographic characteristics of the patient and control groups are shown in Table 1. Age, body mass index, and education level were not different between the groups. The sedimentation, C-reactive protein and lipid profile levels in the patients with FMS were found to be in the normal range and were significantly different from those of the control group.

The level of serum endocan was determined as 394.607 \pm 223.132 $\mathrm{ng} / \mathrm{mL}$ and $235.998 \pm 190.812 \mathrm{ng} / \mathrm{mL}$ in the patient and control groups, respectively. The CIMT was measured as $0.64 \pm 0.13 \mathrm{~mm}$ and $0.47 \pm 0.15 \mathrm{~mm}$ in the patient and control groups, respectively. The serum endocan levels and CIMT were determined to be statistically significantly higher in the patient group than in the control group $(p<0.001)$. In the FMS patients, a very weak correlation was determined between CIMT and endocan levels.

\section{Discussion}

The aim of this study was to evaluate serum endocan levels in patients with FMS and to evaluate any correlation between the serum endocan level and CIMT. The results demonstrated that serum endocan levels and CIMT were higher in patients with FMS than in the healthy population. Furthermore, a correlation between CIMT and endocan levels was determined in patients with FMS.

Table 1. Demographic and clinical characteristics of the patients

\begin{tabular}{|l|l|l|l|}
\hline & $\begin{array}{l}\text { Patient group } \\
\text { Mean } \pm \text { SD }\end{array}$ & $\begin{array}{l}\text { Control group } \\
\text { Mean } \pm \text { SD }\end{array}$ & $\mathbf{p}$ \\
\hline Age (years) & $41.9 \pm 11.0$ & $38.1 \pm 8.8$ & 0.088 \\
\hline BMI $\left(\mathbf{k g} / \mathbf{m}^{2}\right)$ & $24.4 \pm 3.3$ & $23.5 \pm 1.5$ & 0.126 \\
\hline Disease duration (months) & $9.2 \pm 3.5$ & $6.4 \pm 2.2$ & $<0.001$ \\
\hline CIMT $(\mathbf{m m})$ & $0.64 \pm 0.13$ & $0.47 \pm 0.15$ & $<0.001$ \\
\hline Endocan $(\mathbf{n g} / \mathbf{m L})$ & $394.6 \pm 223.1$ & $235.9 \pm 190.8$ & $\mathbf{0 . 0 0 1}$ \\
\hline BMI: Body mass index, CIMT: Carotid intima-media thickness, SD: Standard deviation & & \\
\hline
\end{tabular}




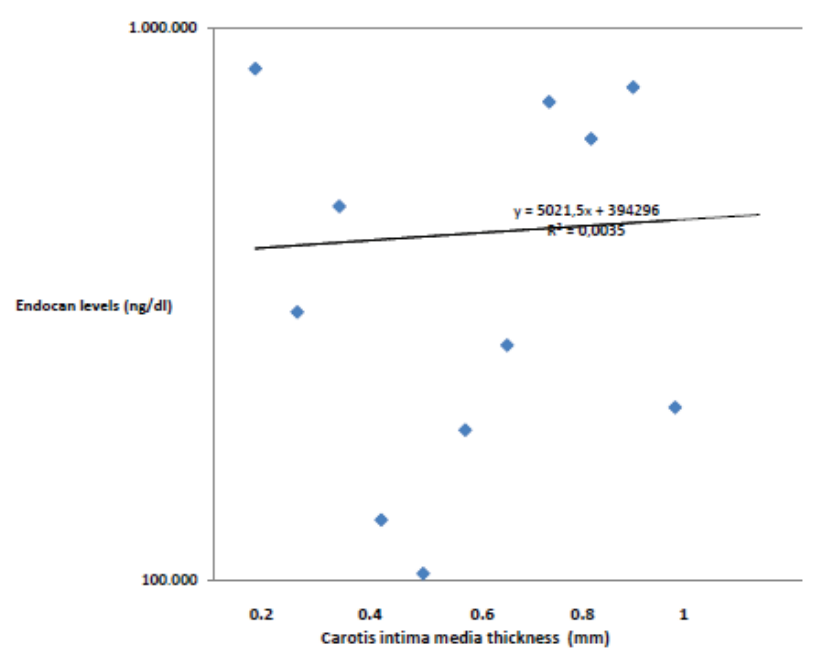

Figure 1. Correlations between serum endocan levels and carotid intima-media thickness values in patients with fibromyalgia

FMS is characterized by chronic musculoskeletal pain, fatigue, sleep disturbance, cognitive dysfunction, and depression $(9,10)$. Stress and pain have been reported to increase the activity of the sympathetic nervous system (SNS) in patients with FMS (11-13). The arterial wall thickening process is significantly affected by SNS activity, leading to alterations in cardiovascular system responses and causing endothelial damage (14). It has also been suggested that a high catecholamine level may have a significant role in FMS pathophysiology (15). With consistent activation of calcium channels, membrane damage, and microvascular spasm may be responsible for catecholamineinduced endothelial dysfunction mechanisms (16).

Topal et al. (17) reported that asymmetric dimethylarginine levels associated with endothelial dysfunction are elevated in patients with FMS. They also determined a positive correlation between 8-iso-prostaglandin F2a (8-iso-PGF2 $\alpha$ ), which is an important indicator of oxidative stress and lipid peroxidation, and TNF- $\alpha$, which is a proinflammatory cytokine (17). Another study demonstrated correlations between elevated IL-6 and IL-8 levels in patients with FMS and the severity of disease symptoms (18). Sánchez-Dominguez et al. (19) reported that TNF- $\alpha$ levels measured in skin biopsies were correlated with serum levels patients with FMS, suggesting that an increase in oxidative stress leads to inflammation. In conclusion, a greater risk of endothelial dysfunction and atherosclerosis may be inevitable in FMS patients (20).

Endocan is a novel human endothelial cell specific molecule. Elevated endocan levels may indicate endothelial dysfunction in different pathologies $(21,22)$. CIMT is a strong indicator of early atherosclerosis and cardiovascular disease and is commonly used in rheumatological diseases to assess the risk of cardiovascular disease $(23,24)$. In addition, CIMT values are associated with certain clinical parameters (such as lengthy disease duration, degenerations, high inflammatory parameters, and extra-articular symptoms) in diseases, such as rheumatoid arthritis (25). In the literature, studies have shown the presence of early atherosclerosis with increased CIMT values in ankylosing spondylitis, rheumatoid arthritis and Behçet's disease compared to a healthy population $(26,27)$. In addition, high serum endocan levels and increased CIMT in patients with FMS have been shown in different studies $(28,29)$.

Previous studies have reported that endocan levels and CIMT are correlated in inflammatory diseases $(7,8)$. Therefore, in the current study, serum endocan levels and CIMT were measured in patients with FMS. Although a correlation was determined between CIMT and endocan levels in the FMS patients, it is difficult to explain the increase in CIMT in this patient group by increased endocan levels alone, although this finding sheds light on a possible mechanism (Figure 1). Due to the complexity of the disease pathogenesis and presence of different risk factors that cannot be controlled, there is a need to investigate possible markers that may be associated with increased CIMT in a larger case series.

\section{Conclusion}

In conclusion, the results of this study demonstrated that serum endocan levels and CIMT were higher in patients with FMS than in the healthy population. Furthermore, a correlation was found between CIMT and endocan levels in the FMS patients. These results indicate the presence of increased subclinical inflammation, endothelial dysfunction, and early atherosclerosis in FMS and present a potentially significant mechanism in the pathophysiology of FMS. These patients should be followed up more carefully in terms of atherosclerotic and cardiovascular problems in the long term.

There were some limitations to this study, primarily that only females were included, so the effect of gender on CIMT in patients with FMS was not evaluated. Furthermore, the sample size was relatively small. There is a need for multicenter studies conducted with larger series of patients with FMS.

\section{Ethics}

Ethics Committee Approval: The study were approved by the Kafkas University Faculty of Medicine of Local Ethics Committee (protokol no: 80576354-050-99/131).

Informed Consent: Consent form was filled out by all participants.

Peer-review: Internally peer-reviewed.

\section{Authorship Contributions}

Surgical and Medical Practices: F.B., F.H.T., Concept: F.B., F.H.T., Design: F.B., Data Collection or Processing: F.B., F.H.T., Ö.K., Analysis or Interpretation: F.B., F.H.T., Ö.K., Literature Search: F.B., F.H.T., Ö.K., Writing: F.B.

Conflict of Interest: No conflict of interest was declared by the authors.

Financial Disclosure: The authors declared that this study received no financial support. 


\section{References}

1. Littlejohn G, Guymer E. Neurogenic inflammation in fibromyalgia. Semin Immunopathol 2018;40:291-300.

2. Bölük H, Öztürk GT, Cömert D, Ersöz M. Increased carotid intima-media thickness in female patients with fibromyalgia: a preliminary study. Arch Rheumatol 2015:30:307-10.

3. Tsai PS, Fan YC, Huang CJ. Fibromyalgia is associated with coronary heart disease: a population-based cohort study. Reg Anesth Pain Med 2015;40:37-42.

4. Wallace DJ, Linker-Israeli M, Hallegua D, Silverman S, Silver $\mathrm{D}$, Weisman $\mathrm{MH}$. Cytokines play an aetiopathogenetic role in fibromyalgia: a hypothesis and pilot study. Rheumatology (Oxford) 2001;40:743-9.

5. Tsilioni I, Russell IJ, Stewart JM, Gleason RM, Theoharides TC. Neuropeptides $\mathrm{CRH}, \mathrm{SP}, \mathrm{HK}-1$, and Inflammatory Cytokines IL-6 and TNF Are Increased in Serum of Patients with Fibromyalgia Syndrome, Implicating Mast Cells. J Pharmacol Exp Ther 2016;356:664-72.

6. García JJ, Cidoncha A, Bote ME, Hinchado MD, Ortega E. Altered profile of chemokines in fibromyalgia patients. Ann Clin Biochem 2014;51:576-81.

7. Icli A, Cure E, Cure MC, Uslu AU, Balta S, Mikhailidis DP, et al. Endocan Levels and Subclinical Atherosclerosis in Patients With Systemic Lupus Erythematosus. Angiology 2016;67:749-55.

8. Lv Y, Zhang Y, Shi W, Liu J, Li Y, Zhou Z, et al. The Association Between Endocan Levels and Subclinical Atherosclerosis in Patients With Type 2 Diabetes Mellitus. Am J Med Sci 2017;353:433-8.

9. Wolfe $F$, Smythe HA, Yunus MB, Bennett RM, Bombardier $C$ Goldenberg DL, et al. The American College of Rheumatology 1990 Criteria for the Classification of Fibromyalgia. Report of the Multicenter Criteria Committee. Arthritis Rheum 1990;33:160-72.

10. Ünübol Ai, Bozbaş $G T$, Ünübol $M$, Gürer $G$. An Evaluation of Mean Platelet Volume and Serum Lipid Profile in Patients with Fibromyalgia Syndrome. Arch Rheumatol 2013:251-5

11. Giske L, Vøllestad NK, Mengshoel AM, Jensen J, Knardahl S, Røe C. Attenuated adrenergic responses to exercise in women with fibromyalgia-a controlled study. Eur J Pain 2008;12:351-60.

12. Martinez-Lavin M. Biology and therapy of fibromyalgia. Stress, the stress response system, and fibromyalgia. Arthritis Res The 2007;9:216.

13. Lee JH, Cho KI, Kim SM, Lee HG, Kim TI. Arterial stiffness in female patients with fibromyalgia and its relationship to chronic emotional and physical stress. Korean Circ J 2011;41:596-602.

14. Cho KI, Lee JH, Kim SM, Lee HG, Kim TI. Assessment of endothelial function in patients with fibromyalgia-cardiac ultrasound study. Clin Rheumatol 2011;30:647-54.

15. Wittstein IS, Thiemann DR, Lima JA, Baughman KL, Schulman SP, Gerstenblith G, et al. Neurohumoral features of myocardia stunning due to sudden emotional stress. N Engl J Med 2005;352:539-48
16. Zaroff JG, Rordorf GA, Titus JS, Newell JB, Nowak NJ, Torchiana DF, et al. Regional myocardial perfusion after experimental subarachnoid hemorrhage. Stroke 2000;31:1136-43.

17. Topal G, Donmez A, Doğan BS, Kucur M, Cengiz DT, Berkoz FB, et al. Asymmetric dimethylarginine (ADMA) levels are increased in patients with fibromyalgia: correlation with tumor necrosis factor- $\alpha$ (TNF- $\alpha$ ) and 8-iso-prostaglandin $F(2 \alpha)$ (8-iso-PGF $(2 \alpha)$ ). Clin Biochem 2011:44:364-7.

18. Mendieta D, De la Cruz-Aguilera DL, Barrera-Villalpando MI, Becerril-Villanueva $E$, Arreola $R$, Hernández-Ferreira $E$, et al. IL-8 and IL-6 primarily mediate the inflammatory response in fibromyalgia patients. J Neuroimmunol 2016;290:22-5.

19. Sánchez-Domínguez B, Bullón P, Román-Malo L, Marín-Aguilar F, Alcocer-Gómez E, Carrión AM, et al. Oxidative stress, mitochondrial dysfunction and, inflammation common events in skin of patients with Fibromyalgia. Mitochondrion 2015;21:69-75.

20. Tsai PS, Fan YC, Huang CJ. Fibromyalgia is associated with coronary heart disease: a population-based cohort study. Reg Anesth Pain Med 2015;40:37-42.

21. Kul A, Ateş O, Alkan Melikoğlu M, Uğur M, Öztürk N, Erkayhan $\mathrm{G}$, et al. Endocan Measurement for Active Behçet Disease. Arch Rheumatol 2017;32:197-202.

22. Kim KS, Lee YA, Ji HI, Song R, Kim JY, Lee SH, et al. Increased expression of endocan in arthritic synovial tissues: effects of adiponectin on the expression of endocan in fibroblast-like synoviocytes. Mol Med Rep 2015;11:2695-702.

23. Tutoğlu A, Boyaci A, Boyaci N, Kaya Z, Aridici R, Koca I. Is There Any Relationship between Joint Destruction and Carotid Intimamedia Thickness in Patients with Rheumatoid Arthritis? J Phys Ther Sci 2014;26:1093-6.

24. Mohan A, Sada S, Kumar BS, Sarma KV, Devi BV, Rao PV, et al. Subclinical atherosclerosis in patients with rheumatoid arthritis by utilizing carotid intima-media thickness as a surrogate marker. Indian J Med Res 2014;140:379-86.

25. Targońska-Stepniak B, Drelich-Zbroja A, Majdan M. The relationship between carotid intima-media thickness and the activity of rheumatoid arthritis. J Clin Rheumatol 2011;17:249-55.

26. Gupta N, Saigal R, Goyal L, Agrawal A, Bhargava R, Agrawal A. Carotid intima media thickness as a marker of atherosclerosis in ankylosing spondylitis. Int J Rheumatol 2014;2014:839135.

27. Gauri LA, Fatima Q, Diggi S, Khan A, Liyakat A, Nagar K. Study of Carotid Artery Intimomedial Thickness in Patients with Rheumatoid Arthritis and its Co-relation with Severity of the Disease. J Assoc Physicians India 2017:65:37-40.

28. Bölük H, Öztürk GT, Cömert D, Ersöz M. Increased Carotid Intima-Media Thickness in Female Patients With Fibromyalgia: A Preliminary Study. Arch Rheumatol 2015:307-31.

29. Mertoglu C, Gunay M, Yerligok O. Could Endocan, a Marker of Inflammation and Endothelial Dysfunction, be a New Diagnostic Marker for Fibromyalgia? Clin Lab 2018:64:405-10. 